\title{
EFFECTS OF ANXIETY IN LEARNING SECOND LANGUAGE: A STUDY ON THE PUBLIC SECONDARY SCHOOL STUDENTS
}

\author{
Shazia Inayat Ali \\ Lecturer, \\ Department of Education, Jinnah University for Women, Karachi \\ Sindh, Pakistan \\ Email: saasrani@yahoo.com \\ Saba Shakeel \\ Lecturer, \\ Department of Education, Jinnah University for Women, Karachi \\ Sindh, Pakistan \\ Email: $\underline{\text { sabashakeel2003@gmail.com }}$ \\ Farheen Shakir \\ Research Scholar, \\ Department of Education, Jinnah University for Women, Karachi \\ Sindh, Pakistan \\ Email: farheenmairaj@yahoo.com
}

\begin{abstract}
The main purpose of the study is to investigate the causes of anxiety which effect among the students of English language at secondary level. The data has been collected from the 100 students of secondary level of public schools using a survey questionnaire comprised of 24 items. There are 18 towns in Karachi for this study; as a sample frame New town was selected. The total of particepants 100 as the samples size was selected through purposive sampling group of 50 female and 50 male students from public schools. All dimensions are reliable, it is confirmed by reliability analysis. The adopted questioner grouping has been confirmed by the outcomes of the factor analysis. One sample test also shows the significant difference. At last, the regression analysis indicates a significant relationship between student language learning anxiety, classroom environment, the teacher's role and test anxiety. The research suggests a strong intervention by the second language teachers to provide a conducive environment to the students. The teacher must try their level best to create an effective teaching learning process and the teacher training institutions should teach the strategies to reduce the test anxiety among the students.
\end{abstract}




\section{KEYWORDS}

Anxiety, Second language, Public schools

\section{INTRODUCTION}

Globalization is a standout amongst the most important phenomena which have made its effect on every aspect of life. The things which were once considered local are now global in nature and context. As the world is moving on, the challenges of human life are increasing. It is generally assumed that globalization has created negative consequences, however, several reports (UN, 1989; UNICEF, 2003) stated that globalization has significantly contributed in every walk of life. It has also promoted and has impacted human in the field of economics and education and has widened the domain of language as well. Since language is the reflection of society, it has also contributed in sharing and promoting a global phenomenon. In a broader perspective, language has opened a forum for the people to learn, to disseminate and to share knowledge in a global context so that the pool of knowledge can be scattered over the globe somewhat restricted in a constrained place and time. Language is a systematic art of communication (Goldstein, 2008) to express feelings and articulation. This expressive mode of communication between human who either express either orally or in the writing form, in a structured and conventional way (Sapir, 1921). On the off chance that we investigate the historical backdrop of language, we will find that language has dependably moved types of communication.

The cultural phenomena have influenced human interaction. Language is a learned behavior. It distinguishes the human being from the animal and the ability to learn. Not only is this but it the exclusive quality of human being. (Chomsky, 1988). There is a connection amongst languages and culture. We can't survive without it. A language is a developmental process in which a child learns language by using basic a skill system of information (Moeen, 1992). The learning process continues till the child is able to understand the worldly context. Moreover, the cultural impact is highly influential which can be observed in the language child speaks. Language is the main instrument, which helps us to communicate with other individuals all around the world. A Communication is the multidisciplinary workmanship to see rather yelling or perplexing. This art is the best mode of self-expression it keeps us in contact with the rest of the global world and language learning boost brain power.

English is the national language of many countries which include America and is considered as a green passport all over the world. In view of globalization, the spread of English language can be seen all through the world. English language is a condensed language which has reached to the level of maturation in the 19th century. Today English dialect has the most well-known everywhere throughout the world since it isn't just considered as the first language of around a huge number of speakers 
in numerous nations yet additionally utilized as a part of worldwide language. The most widely recognized factor related to the learning of the English language is Anxiety. Anxiety is a piece of the human condition. When we learn new languages, we frequently feel anxiety which is portrayed by a diffuse, unsavory, unclear feeling of fear, regularly joined via autonomic effects, for example, headache, sweat, palpitations, tightness in the chest, and moderate stomach distress (Kaplan, 1996). These experiences are frequently connected with the sentiment strain, apprehension and stress (Spielberger, 1983). When we are anxious, we also feel worried we face many pressures such as trembling. Simple anxiety is said to have an associated with unpleasant feelings (Lader, 1975). Foreign language classroom anxiety has been broadly explored by the prestigious researchers. It is generally assumed that Students may be good at many learning scales, but when it comes to learn other languages, they find it difficult and considered it as a mental block (Horwitz, 1986). Saito (1999) found that students experience low levels of reading anxiety then general foreign language classroom environment.

When we communicate second language, we feel anxiety, there is also agreement that anxiety is related to performance (Balachandrain \& shully, 2004; Tobia \& Everson, 1997). Student specifically in school confronts secondary language issue. Looking to the scenario of Language learning in Pakistan, there are many conflicts, which are taking place since independence. Language has taken many shapes and forms in Pakistan and it is due to many reasons out of which one of the reasons is political influence. As indicated by the Constitution of Pakistan (1973) The National language of Pakistan is Urdu. However, the medium of direction is either Urdu or English. English is commonly used in educational institutions and it is the language, necessary to obtain a better position in society.

Harr (2008) stated knowledge is constructed by the learner as mentor provide pastoral guidance for their intellectual development English language learners process their learning by reading and understand English. Throughout the world second language is considered as a problematic because it is hard to adapt and adopt another language. We feel comfortable using first language, however things are not the same for second languages. English is the second and official language in Pakistan and in addition a simple language to work with and learn multi-disciplinary subject. Most of the students cannot communicate properly in English and see it as an extremely troublesome subject. For the enjoying the status and use the second language effectively. It is necessary to master four skill, namely reading, writing, speaking, listening (Aronoff \& Ree Miller, 2007). The difficulties the students are confronted while adapting second language should be investigated by the experts. In Pakistani context, this case study will highlight the relation of the anxiety with the second language learning. So, specific methodologies can be implemented to beat it. The 
significance of researching gender wise student's reaction, inspiration and anxiety in an eastern setting makes this investigation more noteworthy. The Pakistani students are mostly second Language learning of English Language, they possess a high level of apprehensions while learning the English language and they can't express and explain their apprehensions which by the passage of time, lead to several Psychological problems. Feeling of anxiety is reported very commonly because they express student negative emotional reaction towards English language learning such as tension, nervousness and worries and many other problems (Bhatti, 2016 ).

\section{CONCEPTUAL FRAME WORK}

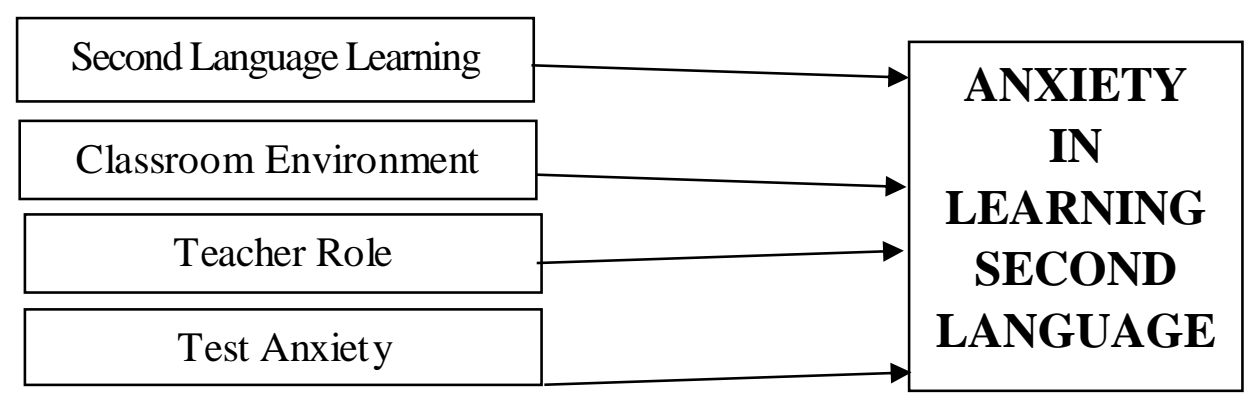

\section{LITERATURE REVIEW}

Tran, Karen, and Richard (2012) this research, investigate anxiety encounters by tertiary students in learning English as a foreign language (EFL). The researchers collected the data by means of Interview and observation tools; data have been analyzed through content analysis approach facilitated by ANOVA. The results showing that awareness of the significance of English and volition were two vital factors that affected anxious student's assurance to think about English. The research proposes that student's awareness of the significance of English ought to be improved, and that they volitional methodologies ought to be reinforced, so as to help them in dealing with their anxiety viably and consequently to persevere in EFL learning.

Rochelle, Edna and Dianne (2011) the research proposed to inquire the anxious foreign students of English language learning in the Philippines. Foreign Language Classroom Anxiety Scale (FLCAS) and Language Strategy Survey (LSS). The data is analyzed through the Descriptive statistical, Standard Deviation (SD), Pearson correlation and multiple regression analysis. As per findings, in order to cope up English class anxiety students used vocabulary strategy for efficient learning. Therefore, it is discovered that the work of this strategy empowers the students to assume responsibility for their own learning as this fills in as their essential guide to learn other full-scale abilities in the selected language. 
Şenel (2016) this study proposed to discover anxiety levels in learning foreign language students. The study was carried out at the Faculty of English Language and Literature at Cumhuriyet University, Sivas, Turkey. Foreign Language Classroom Anxiety Scale used to gather data. Statistical package for the social sciences (SPSS) 18.0 utilize to analyze data. This study recommends that an educator plays an imperative part of student learning decisions, encounters. The study also recommends that it is instructor's obligations that ought to recognize the reason for foreign language anxiety and attempt to help their students or make the effective classroom condition with the goal that their students would figure out how to convey instead of dread the language.

Lana (2014) the study found that whether foreign language learning anxiety is present from the earliest starting point of the language learning process. The technique for information gathering was the focus group interview. Mean, median Std. Deviation method used for analysis. It is essential to teach youthful students how to manage any anxiety they may experience, at this level, or later on, so they can be more inspired and more successful in their foreign language learning.

Husey (2015) the purpose behind the study to discover what the elements of foreign (English) language learning anxiety are, particularly among Turkish understudies of EFL; the statistics have been gathered Turkish students, questionnaire, experiment and statistical investigation of got through questionnaire surveys and experiment data. Thus, the strategies for inquiring about were quantitative and factual. The study proposes this is extremely noteworthy for Turkish students learning English, as, from one viewpoint, they have certain partialities concerning learning foreign languages (which is went with finding out about the corresponding cultures), and, then again, female students in Turkey have to follow behavior rules that they feel fear to break.

Horwitz, Michael B. Horwitz, and Joann Cope (1986) shaped the reason for the research and in addition an oral survey in view of things utilized by Von Worde (2003). The scoring guide for the FLCAS utilizing to analyze data, which is the 33-thing self-reporting instrument to graph the participant's scores. The findings demonstrated that among this gathering of ESL/foreign language students, powerlessness in learning a second language was not contributed by anxiety.

This study analyzes the anxiety level of foreign language youthful, adolescent students in connection to language aptitudes at various levels. Data from total 160 Turkish students of English as a foreign language classroom was collected by using a modified version of the Foreign Language Classroom Anxiety Scale (FLCAS) (Horwitz, et al, 1986). The finding of this research uncovers that the foreign language anxiety faced by youthful adolescent students varies with connection to 
levels of teaching and to fundamental language abilities. Foreign language anxiety is accounted for in open abilities at beginner levels and after that in productive aptitudes as the levels progress. In view of the present findings, it is proposed that the students' level of guidelines and the type of significant anxieties they may experience in connection to aptitudes ought to be considered when foreign language educational modules and in-class exercises are developed.

Mei-Ling, research study proposed the connection between English learning anxieties (correspondence anxiety, test anxiety, and dread of negative assessment), among EFL non- English major students. Strength of 254 first year recruits at a proceeding with school in Taiwan, including 145 male and 109 female students participated in this investigation. A questionnaire ELAS (English Learning Anxiety Survey), to understand participants inward considerations as far as English language learning anxieties among three classifications, was in part modified from FLCAS (foreign language classroom anxiety scale) and somewhat planned by the researcher. The statistic was then analyzed by utilizing descriptive statistics, ANOVA, Post Hoc Test. The outcomes demonstrated that there were factually noteworthy contrasts on the English Learning Anxiety Scale (ELAS) as for these three classifications of anxiety, communication, test, and dread of negative assessment among EFL college first year recruits. Additionally, of these three classes of English learning anxiety, the most noteworthy mean score over the things was test anxiety, trailed by communication anxiety and dread, lastly of negative assessment. Also, Commercial Design students were having the most elevated anxiety scales, trailed by the individuals Industrial Engineering students and Management and Cosmetology and Styling. The most minimal level of anxiety was noted among students of Mechanical Engineering, trailed by the individuals of Electrical Engineering and Applied Foreign Languages.

\section{RESEARCH OBJECTIVES}

The main purpose of the study is to investigate the factors associated with the causes of anxiety among the students of English language at secondary level.

1. To investigate, how secondary students experience anxiety in their language learning.

2. To figure out the factor more probable to cause anxiety.

3. To understand the role of teachers in developing language skills among student of secondary school learner and to overcome the anxiety.

4. To analyze the impact of environment/surrounding on the learning of a second Language.

\section{RESEARCH HYPOTHESIS}

The hypothesis constructed for this research are as follow: 
1. There will be no significance difference in the anxiety level of public school.

2. There will be no significance role of teachers in promoting anxiety among the students.

3. There will be no significance difference role of environment in promoting anxiety among the students of public school.

4. There will be no significance difference role of test promoting anxiety among the students of public school.

\section{RESEARCH METHODOLOGY}

From all the reviews, this paper has adopted the one sample t- test, reliability and regression test to check the results.

Whereas SLL Second Language Learning, CEN Classroom Environment, TR Teacher Role, TA Test Anxiety. A survey research questionnaire of 24 items has been used to collect the data of 100 students of public school at secondary level. The one sample test use to determine whether a sample comes from a population with a specific mean. This population mean is not always known, but is sometimes hypothesized.

\section{Table 1}

Test Value $=5$

\begin{tabular}{lllcc}
\hline & T & df & Sig. (2- & Mean Difference \\
\hline SLL & -7.430 & 99 & .000 & -.690 \\
TR & -12.241 & 99 & .000 & -1.460 \\
CEN & -15.955 & 99 & .000 & -1.320 \\
TEST & -9.419 & 99 & .000 & -.930 \\
\hline
\end{tabular}

Moving left to right $\mathrm{t}-$ value $(\mathrm{t}=$ column), the degree of freedom $(\mathrm{df})$, and the statistical significance ( $p$ - value) Sig. (2-tailed) of the one sample t- test. If the $p<.05$ Therefore, itcan be concluded that the population means are statistically significant different. If $\mathrm{p}$ $>.05$, the different between sample estimated population mean and the comparison mean would not be statistically significant different.

According to the above Table 1

Hyp 1:

There is statistically significantly different between means $(\mathrm{p}<.05),(.000<0.05)$ and, therefore, we reject the null hypothesis means. There is significantly different between the anxiety levels of public school.

\section{Hyp 2:}

There is statistically significantly different between means $(\mathrm{p}<.05),(.000<0.05)$ and, 
therefore, we reject the null hypothesis means. There is significance role of teachers in promoting anxiety among the students.

\section{Hyp 3:}

There is statistically significantly different between means $(\mathrm{p}<.05),(.000<0.05)$ and, therefore, we reject the null hypothesis means. There is significance role of environment in promoting anxiety among the students of public school.

\section{Hyp4:}

There is statistically significantly different between means $(\mathrm{p}<.05),(.000<0.05)$ and, therefore, we reject the null hypothesis means. There is significance role of test promoting anxiety among the students of public school.

\section{Reliability analysis}

Table, 2 represents reliability test results. Outcome of reliability analysis of overall questionnaire describes that the Cronbach's alpha shows a value that is considered good. It implies that the researchers will get consistent results by using this instrument, also the instrument and data are almost reliable because value of Cronbach's alpha of the overall questionnaire is 0.894 . For any further estimation our data and the instrument are reliable confirmed by the results of the reliability analysis.

Table 2: Reliability Statistics

\begin{tabular}{|c|c|c|}
\hline $\begin{array}{l}\text { Cronbach's Alpha } \\
\text { Cronbach's Alpha }\end{array}$ & $\begin{array}{l}\text { Cronbach's Alpha Based on Standardized } \\
\text { Items }\end{array}$ & $\begin{array}{l}\mathrm{N} \text { Of Items } \\
\mathrm{N} \text { of Items }\end{array}$ \\
\hline .894 & .878 & 24 \\
\hline
\end{tabular}

\section{Regression Analysis}

Hyp1 = There is no relationship between the second language learning anxiety and the students of Public school

Table 3: Model Summary

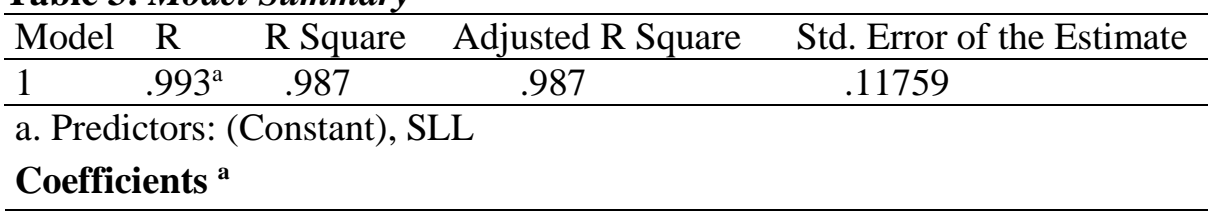

Model Unstandardized Coefficients $\begin{aligned} & \text { Standardized } \\ & \text { Coefficients }\end{aligned}$




\begin{tabular}{llllll}
\hline & B & Std. Error & Beta & & \\
\hline 1 (Constant) & .251 & .041 & & 6.150 & .000 \\
SLL & .148 & .002 & .993 & 85.308 & .000 \\
\hline
\end{tabular}

a. Dependent Variable: Students of Public school

The level of significant in the coefficient Model is less than 0.05 which is 0.000 it shows that $(\mathrm{H} 0)$ is reject. There is significant relationship between the students of Public school and second language leaning anxiety. It means that the second language learning anxiety effect of students of Public school and increase the other factors among the students alone with anxiety.

Hypo 2 =There is no relationship between the anxiety among the Public school student and role of teachers in promoting anxiety

Table 4: Model Summary

\begin{tabular}{lllll}
\hline Model & $\mathrm{R}$ & R Square & Adjusted R Square & $\begin{array}{l}\text { Std. Error of } \\
\text { the Estimate }\end{array}$ \\
\hline 1 & $.953^{\mathrm{a}}$ & .909 & .908 & .30749 \\
\hline
\end{tabular}

a. Predictors: (Constant), TR

Coefficients $^{\text {a }}$

\begin{tabular}{lllllcll}
\multicolumn{1}{c}{$\begin{array}{c}\text { Unstandardized } \\
\text { Coefficients }\end{array}$} & \multicolumn{2}{c}{$\begin{array}{c}\text { Standardized } \\
\text { Coefficients }\end{array}$} \\
& Model & B & Std. Error & Beta & T & & Sig. \\
\hline 1 & (Constant) & -1.849 & .176 & & 10.482 & .000 & \\
& R OF T & .247 & .008 & .953 & 31.313 & .000 & \\
\hline
\end{tabular}

The level of significant in the coefficient Model is less than 0.05 which is 0.000 it shows that (H0) is reject. There is significant relationship between the anxiety among the students and Role of teachers. It means that if the teachers play effective role and reduce to promote anxiety among the public-school student it helps to reduce the anxiety among the students.

Hypo3 $=$ There is no relationship between the anxiety among the public student and the role of environment in promoting anxiety

Table 5: $\quad$ Model Summary

\begin{tabular}{lclll}
\hline Model & $\mathrm{R}$ & $\mathrm{R}$ Square & $\begin{array}{l}\text { Adjusted } \mathrm{R} \\
\text { Square }\end{array}$ & Std. Error of the Estimate \\
\hline 1 & $.970^{\mathrm{a}}$ & .942 & .941 & .24636 \\
\hline a. Predictors: (Constant), environment \\
\hline
\end{tabular}




\begin{tabular}{lllllll} 
Coefficients $^{\text {a }}$ & \multicolumn{1}{l}{} \\
\hline & & \multicolumn{2}{l}{ Unstandardized } & Standardized & & \\
& & Coefficients & Coefficients & & \\
& Model & $\mathrm{B}$ & Std. Error & Beta & $\mathrm{T}$ & Sig. \\
\hline 1 & (Constant) & -2.207 & .148 & & -14.930 & .000 \\
& environment & 1.641 & .041 & .970 & 39.776 & .000 \\
\hline
\end{tabular}

a. Dependent Variable: Students of Public school

The level of significant in the coefficient Model is less than 0.05 which is 0.000 it shows that $(\mathrm{H} 0)$ is reject. There is significant relationship between the anxiety among the students and environment. It means that if school provide the conducive environment and reduce the promoting anxiety factors in the environment, its effect and reduce the student learning second language anxiety.

Hypo $4=$ There is no relationship between the anxiety among the public students and role of test anxiety

Table 6: Model Summary

\begin{tabular}{lllll}
\hline Model & R & R Square & Adjusted R Square & $\begin{array}{l}\text { Std. Error of the } \\
\text { Estimate }\end{array}$ \\
\hline 1 & $.974^{\mathrm{a}}$ & .949 & .949 & .22951 \\
\hline
\end{tabular}

a. Predictors: (Constant), TA

\section{Coefficients $^{\text {a }}$}

\begin{tabular}{ccccccc}
\hline & \multicolumn{7}{c}{$\begin{array}{c}\text { Unstandardized } \\
\text { Coefficients }\end{array}$} & $\begin{array}{c}\text { Standardized } \\
\text { Coefficients }\end{array}$ & & \\
& Model & $\mathrm{B}$ & Std. Error & Beta & T & Sig. \\
\hline 1 & (Constant) & -.472 & .097 & & -4.842 & .000 \\
& TA & .149 & .003 & .974 & 42.871 & .000 \\
\hline
\end{tabular}

a. Dependent Variable: students od Public school

The level of significant in the coefficient Model is less than 0.05 which is 0.000 it shows that $(\mathrm{H} 0)$ is reject. There is significant relationship between the anxiety among the students and the role of test. It means that test anxiety effect on public school student in second language learning. If test anxiety reduces its help to reduce the second language anxiety among the public students.

\section{CONCLUSION}

The result concludes that the public-school student place a significant in rising anxiety in second Language class. The role of the teacher is very important to reduce anxiety in second Language class. The result also revealed that confidence, communication skill is very important to develop confidence in second Language class through effective teaching learning process. The encouragement of the teacher to the students 
can also significantly reduce anxiety, when they speak. Conducive Environment plays a significant role in reducing anxiety among second Language learner. The result also revealed that students are more concern about second Language but unfortunate.

\section{RECOMMENDATION}

1. The research suggests strong intervention by the second language teachers to provide an effective teaching to the students.

2. The teacher must try their level best to take the easy Language test and remove the focus of communication skill all the teacher training institutions should teach the strategies to reduce anxiety of the suggests.

3. Try to create a conducive environment in which student feels more comfortable to communicate and practice second language. There should be an activity-based learning in which student enjoying rather than pointing to each other or make any discomfort situation.

4. Further researches can be conducted on finding correlation of Language anxiety. 5. Majority students in Pakistan have less than 2\% functional in verbal and written. This is important that Urdu replace at the federal level, National and district level in English. It will help to manage the social status.

\section{REFERENCES}

Aida, Y. (1994). Examination of Horwitz, Horwitz, and Cope's construct of foreign language anxiety: The case of students of Japanese. The modern language journal, 78(2), 155168.

Aronoff, M. (2007). Language (linguistics). Scholarpedia, 2(5), 3175. Aronoff, M. (2007). Language (linguistics). Scholarpedia, 2(5), 3175.

Bhatti, N. (2016 ). Investigating the Perceptions of Pakistani English Language Learners on Language Learning Anxiety in EFL Classroom . Advances in Language and Literary Studies.

Chastain, C. B., Carithers, R. W., Hogle, R. M., Abou-Gabal, M., Graham, C. L., \& Branstetter, D. (1976). Dermatophilosis in two dogs. Journal of the American Veterinary Medical Association, 169(10), 1079-1080.

Chomsky, N. (1988). Language and problems of knowledge: The Managua lectures (Vol. 16).

Cook, V. (2001). Using the first language in the classroom. Canadian modern language review, 57(3), 402-423.

Crystal, D. (2013). A global language. In English in the World(pp. 163-208). Routledge.

Fornell, C., \& Larcker, D. F. (1981). Structural equation models with unobservable variables and measurement error: Algebra and statistics. Journal of marketing research, 382-388.

Gilbert, P., McEwan, K., Matos, M., \& Rivis, A. (2011). Fears of compassion: Development of three self-report measures. Psychology and psychotherapy: theory, research and practice, 84(3), 239-255. 
Gefen, D., \& Straub, D. (2005). A practical guide to factorial validity using PLS-Graph: Tutorial and annotated example. Communications of the Association for Information systems, 16(1), 5 .

Goldstein, M., \& Udry, C. (2008). The profits of power: Land rights and agricultural investment in Ghana. Journal of political Economy, 116(6), 981-1022.

Harr, K. E., Allison, K., Bonde, R. K., Murphy, D., \& Harvey, J. W. (2008). Comparison of blood aminotransferase methods for assessment of myopathy and hepatopathy in Florida manatees (Trichechus manatus latirostris). Journal of Zoo and Wildlife medicine, 39(2), 180187.

Horwitz, E. K., Horwitz, M. B., \& Cope, J. (1986). Foreign language classroom anxiety. The Modern language journal, 70(2), 125-132.

Hussey, N. E., Kessel, S. T., Aarestrup, K., Cooke, S. J., Cowley, P. D., Fisk, A. T., ... \& Flemming, J. E. M. (2015). Aquatic animal telemetry: a panoramic window into the underwater world. Science, 348(6240), 1255642.

Hair, J. F., Sarstedt, M., Ringle, C. M., \& Mena, J. A. (2012). An assessment of the use of partial least squares structural equation modeling in marketing research. Journal of the academy of marketing science, 40(3), 414-433.

Kaplan, R. S., \& Norton, D. P. (1996). The balanced scorecard: translating strategy into action. Harvard Business Press.

Kaplan, R. S., \& Norton, D. P. (1996). The balanced scorecard: translating strategy into action. Harvard Business Press.

Kleinmann, H. H. (1977). Avoidance behavior in adult second language acquisition. Language learning, 27(1), 93-107.

Lader, M. H. (1975). Characteristics of galvanic skin response in anxiety states. Journal of Psychiatric Research, 12(4), 265-270.

Lana, A., Rodríguez-Artalejo, F., \& Lopez-Garcia, E. (2014). Consumption of Sugar Sweetened Beverages Is Positively Related to Insulin Resistance and Higher Plasma Leptin Concentrations in Men and Nonoverweight Women-3. The Journal of nutrition, 144(7), 1099-1105.

Leech, N. L., \& Onwuegbuzie, A. J. (2005). An array of qualitative data analysis tools: A call for data analysis triangulation. School psychology quarterly, 22(4), 557.

Lucas, R. I., Miraflores, E., \& Go, D. (2011). English language learning anxiety among foreign language learners in the Philippines. Philippine ESL Journal, 7(94-119).

Miller, C. (2007). 'Julle kan ma New York toe gaan, ek bly in die Manenberg': an oral history of jazz in Cape Town. IMAGINING THE CITY, 133.

Moeen, S. (1998). P-T estimates from the Nellore schist belt (India) and evidence for superimposed metamorphic events. Geological Journal, 33(1), 1-15.

Peng, H., Long, F., \& Ding, C. (2005). Feature selection based on mutual information criteria of max-dependency, max-relevance, and min-redundancy. IEEE Transactions on pattern analysis and machine intelligence, 27(8), 1226-1238.

Penny, J. E. T., Friswell, M. I., \& Garvey, S. D. (1994). Automatic choice of measurement locations for dynamic testing. AIAA journal, 32(2), 407-414.

Saito, Y., Utsunomiya, H., Tsuji, N., \& Sakai, T. (1999). Novel ultra-high straining process for bulk materials - development of the accumulative roll-bonding (ARB) process. Acta materialia, 47(2), 579-583. 
Samimy, K. K., \& Rardin, J. P. (1994). Adult language learners' affective reactions to community language learning: A descriptive study. Foreign Language Annals, 27(3), 379390.

Sapir, E. (1921). Language New York. Oxford. (1925): Sound Patterns in Language. L, 1, 3751.

Spielberger, C. D., \& Gorsuch, R. L. (1983). Manual for the state-trait anxiety inventory (form Y):(" self-evaluation questionnaire"). Consulting Psychologists Press, Incorporated.

Tran, T. T. T., Baldauf, R. B., \& Moni, K. (2013). Foreign language anxiety: Understanding its status and insiders' awareness and attitudes. Tesol Quarterly, 47(2), 216-243. 